\title{
Rethinking the Dworkinian Forward-Looking Approach: is Affirmative Action Compatible with Fairness?
}

\author{
Chong Ho Yu \\ Azusa Pacific University, USA \\ Kwok Tung Cheung \\ University of Dayton, USA
}

Abstract

Whether Affirmative Action is a proper way to accomplish social justice in terms of fairness has been an ongoing debate in the United States. Late philosopher Ronald Dworkin was a vocal supporter of Category 4 Affirmative Action, in which preferential treatments for minorities is justified. Dworkin emphasized a forward-looking approach as a means to achieve social justice and overall fairness. In his view, it is not sufficient for black applicants to enjoy preferential treatment now just because in the past their ancestors suffered due to slavery. Rather, a successful argument for affirmative action programs must include a forward-looking justification. To be specific, this policy promises a better educational environment in terms of diversity and promotes a less racially conscious society for all citizens. Additionally, Dworkin often cited the study entitled The Shape of the River to substantiate his claim that special treatment for minorities could amend social injustice and produce fairer outcomes. This article attempts to evaluate this Dworkinian theory on both the principle and practical levels. It concluded that while a neutral or non-interventional policy is insufficient to achieve racial equality, interventions in terms of special treatments and soft quotas are not yet shown to be fair in practice.

Keywords: Action, Affirmative, Compatible, Fairness.

\section{Introduction}

Whether affirmative action is a proper way to accomplish social justice in terms of fairness has been an ongoing debate in the United States. Late philosopher Ronald Dworkin (1931-2013) was a vocal supporter of affirmative action and his contribution to this field is well-recognized. Atman (2001) highlighted the importance of the Dworkinian theory as follows: "Ronald Dworkin's writing on affirmative action has been among the best of the work that liberal jurisprudence has had to offer on matters of race in the years since the end of the Civil Rights Movement in the United States" (p. 241). Although there is no direct and explicit evidence that the Dworkinian theory had been adopted by the US public authorities, and Dworkin was critical of some opinions of the US Supreme Court justices, the widespread endorsement of affirmative action policies by the Supreme Court is compatible with Dworkin's narrative (Sabbagh, 2011).

For example, in June 2003 the US Supreme Court determined by a 5-4 split on the case of Grutter vs. Bollinger regarding the University of Michigan Law School that the consideration of race in university admissions is not contradicted by the Equal Protection Clause of the 14th Amendment to the Constitution. Justice Sandra Day O'Connor wrote in her opinion "today we endorse Justice Powell's view that student body diversity is a compelling state interest that can justify the use of race in university admissions" (Legal Information Institute, 2003, section A, para. 8). This is a view that is consistent with Dworkin's and, despite some disagreement in the reasoning, supported by Dworkin $(1985,2000)$. Specifically, the Supreme Court asserts that affirmative action is acceptable if race is only one of many factors for consideration by university admissions to achieve diversity. This decision reflects two major trends of conceptualization of affirmative action in recent years. First, the race factor in admissions is justified by the rationale that it is only one of several factors. Second, the focus of affirmative action programs has been shifted from reparation to diversity. Actually, the US Supreme Court's decision could be viewed as an actualization of the Dworkinian theory. Given the importance of the Dworkinian theory, it is imperative to evaluate the efficacy of this theory through a multi-disciplinary lens. 


\section{What Are Affirmative Action Programs?}

Different people might conceptualize and implement affirmative action programs differently. The discussion would not be fruitful without a precise definition of an affirmative action program. According to Taylor (2009), an affirmative action program is a spectrum consisting of at least five categories:

Category 1. Formal equality of opportunity: In this approach, an affirmative action program aims to implement a neutral policy to ensure that opportunities are open to everyone regardless of race, gender, religion, or any demographic attribute. This is the original intent of affirmative action advocated by President Kennedy in 1961. Executive Order 10925 signed by President Kennedy states that "it is the plain and positive obligation of the United States Government to promote and ensure equal opportunity for all qualified persons, without regard to race, creed, color, or national origin, employed or seeking employment with the Federal Government and on government contracts" (Kennedy, 1961, para. 2).

Category 2. Aggressive formal equality of opportunity: Instead of neutrality and non-intervention, supporters of Category 2 would aggressively use sensitivity training, external monitoring, and outreach efforts to achieve a fair outcome in admission and employment. For example, the Office of Civil Engagement at the University of Chicago developed a plethora of programs for minority middle school and high school students to learn science, such as the Young Scientist Program and Space Explorers (University of Chicago, 2017).

Category 3. Compensating support: In this approach, special training programs, financial support, mentoring, or tutoring are provided to minorities to compensate for their disadvantages. Executive Order 11625 signed by President Nixon in 1971 is a good example. Under this law, the Federal Government is obligated to provide minorities with additional technical and management assistance to disadvantaged businesses, and to assist in demonstration projects. It is mandatory for the Secretary of Commerce to "establish a center for the development, collection, summarization, and dissemination of information that will be helpful to persons and organizations throughout the Nation in undertaking or promoting the establishment and successful operation of minority business enterprise" (Nixon, 1971, para. 5).

Category 4. Soft quotas: In this method, "bonus points" are added to the selection indices of minorities in admission and employment while no explicit quota is set. It is important to point out that very often explicit point-adding is forbidden. In 2003, the US Supreme Court struck down the proposed admission policy of the University of Michigan, where 20 points out of 100 were added to minority applicants. Nonetheless, sometimes the soft-quota approach is allowed in an implicit way. For example, in 1997 the University of Texas, Austin adopted a new admissions policy that gives more weight to the essay for non-top 10-percent applicants. This admission criterion is based on how well the candidate could overcome adversity, and also takes into account the special circumstance that might affect the candidate's test score and GPA. As a result, the freshman enrollment of minorities surged significantly (Sabbagh, 2011). This policy was challenged by Fisher, a white applicant who was turned down by the university in 2008 (Fisher vs. University of Texas, No. 14-981). After a long legal process, the Supreme Court decided to side with UT, Austin (Liptak, 2016).

Category 5. Hard quotas: As the name implies, this approach aims to achieve a proportional representation of the population by gender and racial composition in the student body and the work force. Today, this category is unacceptable because in Regents of University of California vs. Bakke (1978), the Supreme Court ruled that a university's use of hard quotas in the admission process is unconstitutional (Justia, 2016).

It is the authors' belief that a neutral, non-inference policy as described in Category 1 is incapable of accomplishing social justice. Due to past and current discrimination, many minorities involuntarily inherit certain social stigmas and disadvantages which do not level the playing field. As Boddie (2016) stated, "The very rawness and extent of these [racial] injustices are too disturbing to bear: videos of police killing unarmed African-Americans; reports by the Department of Justice documenting law enforcement's excessive force against, and harassment of African Americans in Baltimore and Ferguson; xenophobic targeting of American Muslims and Mexican Americans by a presidential candidate" (pp. 38-39). In addition, the White Nationalist rally in Charlottesville, Virginia in August 2017 indicates that racism is still alive in America. Therefore, Boddie rightly questioned whether colorblindness is an appropriate response to racial problems. The authors strongly support Categories 2 and 3 interventions as a remedy, and there is no sign that these types of interventions face any widespread rejection or resistance. As previously mentioned, Category 5 had been outlawed, and therefore the remaining controversy concerns Category 4. 


\section{The Dworkinian Theory}

To fully understand and appreciate Dworkin's theory, we need to track the development of his thoughts from Dworkin (1985) to Dworkin (2000). In the Bakke case, four Justices - Chief Justice Burger, and Justices Stewart, Rehnquist, and Stevens - held that the case had an independent case on the grounds of the 1964 Civil Rights Act, a position that Dworkin (1985) criticized. Then, of the five Justices-Brennan, White, Marshall, Blackmun and Powell-who considered whether it was constitutional, Justice Powell held that Bakke had a case and others held otherwise. Eventually, Bakke won because a majority of the Justices believed he had a case on some grounds "even though they disagreed on which" (Dworkin, 1985, p. 305).

Part of Justice Powell's opinion is that universities and colleges may still take race into account as one factor among others. However, regarding the other part, unfortunately the medical school at University of California, Davis, failed on this account by adopting a policy of hard quotas. This immediately became popular among admission offices of universities and colleges because it did not rule out all sorts of affirmative action programs, and it explicitly pointed to the Harvard undergraduate admissions program as a constitutional practice (Dworkin, 1985). Despite the favorable use of this opinion to license certain forms of affirmative action programs, Dworkin disagreed with Powell, claiming that that is not "sufficiently strong in principle to furnish the basis for a coherent and lasting constitutional law of affirmative action" (Dworkin, 1985, p. 314).

Let us take a closer look at Justice Powell's opinion. He held that the racial classifications used in any affirmative action programs are "suspect" classifications which the US Supreme Court should subject to "strict scrutiny," where it is necessary for the defendant to show that there is a compelling governmental interest in the program. Consequently, simply showing that an affirmative action program conceivably may serve the social goal of combating racial discrimination, which involves what is called a "benign racial classification," is not sufficient to pass the strict scrutiny. All affirmative action programs, including that of the medical school of the University of California, Davis, are subject to strict scrutiny, and they would not pass the test because it is "subjective" and "standardless" to determine whether a classification carries "stigma" (Dworkin, 1985, p. 312). However, Dworkin criticized Powell as being inconsistent. Whereas Powell declared the program at the University of California as unconstitutional, he praised the Harvard program as constitutional, even though the latter involved exactly the same "subjective" and "standardless" judgments (Dworkin, 1985).

The idea of stigma leads us to a very important and fundamental insight into Dworkin's view of affirmative action programs. Even though some people believe Bakke is being discriminated against and therefore should be protected by the Civil Rights Act or the Fourteenth Amendment's guarantee of equal protection under the law, Dworkin did not believe the kind of discrimination that Bakke receives is commensurate or symmetrical with what the blacks and other minorities receive because only the latter involves social stigma. As Dworkin put it, Bakke was not "kept out because his race is the object of prejudice or contempt," but only cases of blacks or other minorities are "distinguished by the special character of public insult" (Dworkin, 1985, p. 301). Years later, Dworkin (2000) repeated this fundamental insight and declared this kind of public insult does not "merely close off to [the victims] one or another opportunity open to others," but it is so destructive to its victims' lives such that it "injures them in almost all the prospects and hopes they might conceive" (Dworkin, 2000, p. 407). We may reasonably conclude that, to Dworkin, this fundamental asymmetry is the underlying reason why there are significant differences between malign discrimination (e.g., against blacks) and benign discrimination (e.g., against Bakke), or why it is still fair to have Category 4 affirmative action programs even when some whites lose their places at universities.

It should be noted that, if the Supreme Court had not outlawed hard quotas, Dworkin might have supported it more explicitly. While he acknowledges the conceptual differences between hard quotas and taking race as a factor into consideration, i.e., the difference between Categories 4 and 5 , he believes the differences are merely administrative and symbolic. In effect, the admissions consideration and process under either one of the concepts will be very similar (Dworkin, 1985).

The above ideas are his early thoughts in Dworkin (1985). In Dworkin (2000), his position has shifted a bit, or we may say developed further. We saw that his fundamental insight about the asymmetry of discrimination remains the same. What is new in Dworkin (2000) is his attempt to incorporate the study of "The Shape of the River" (River Study), and his more explicit defense of the fairness of affirmative action programs regarding the Fourteenth Amendment's guarantee of equal protection under the law. As Dworkin (2000) said, these are "two main strands of that debate" (p. 389), empirical and normative. We will defer the discussion of the empirical studies to the next section. Now, let us examine Dworkin's discussion of the normative forward-looking argument. 
It is important to note first that Dworkin, who has famously coined the metaphor that rights trump utilities (Dworkin 1984), is certainly not going to be content with a position that affirmative action is effective and therefore it does not matter whether affirmative action violates some people's rights. That is why, after he favorably presented the River Study, which he sincerely believed to be powerful, empirical proof, he must take up the burden to argue further that it is fair nonetheless. As he said, "Still, if affirmative action is unfair, because it violates the rights of white and other candidates who are refused places or of the few blacks who feel insulted, then it would be improper even if it does make the nation better off" (Dworkin, 2000, p. 401).

Dworkin's argument that affirmative action is fair consists of two steps. The first step is the basis of qualification. The bases of qualification in different competitions or selections are not the same. Some are a matter of "backward-looking achievement" or "natural property," while some are a matter of "forward-looking promise." He used beauty contests as an example and said that the winner is chosen on the basis of her natural property that she has. However, he goes on to say that we do not choose a doctor as a tribute to his or her skill or to reward the doctor for past cures. We choose the doctor whom we expect to do best for us in the future, and we take the doctor's innate talent or past achievements into account only because so far these are good indicators of the doctor's value to us in the future (Dworkin, 2000).

The second step is the mission of a university or college. Unlike private corporations, these higher education institutions have the public responsibilities of envisioning what the community should be like and how it could be benefited. For the students to be better equipped for commercial and professional life, and "better prepared to act as good citizens in a pluralistic democracy," the institutions usually assume that the students need to have "worked and played with classmates of different geographical background, economic class, religion, culture, and - above all, now-race" (Dworkin, 2000, p. 403). In more contemporary language, this is the idea of integration (e.g., Anderson 2010).

In the context of justifying affirmative action programs, the forward-looking argument focuses on how to build a better future for society, whereas the backward-looking argument focuses on punishing the contemporary whites to compensate for the past injustice done to the blacks. According to Dworkin, however, the backward-looking argument is inferior because it does not make much sense to think that one race "owes" another compensation (Dworkin 2000). The forward-looking argument is more convincing. When the higher education institutions have this kind of diversity vision for the community, it makes sense for them to select candidates with the best forward-looking qualifications, which suggests that affirmative action programs are fair.

However, there are two objections. First, there are many ways to achieve diversity and integration on campus. Why should we choose affirmative action for blacks? Second, what if a community has a law firm that does not welcome blacks? To better serve that community, shouldn't there be an affirmative action to select more whites? Dworkin's answer to both questions is basically the same: "The worst of the stereotypes, suspicions, fears, and hatreds that still poison America are coded by color, not by class or culture" (Dworkin 2000, p. 403). And that color is black. Again, this goes back to the aforementioned fundamental insight about the asymmetry of discrimination - only the blacks carry the social stigma and public insult which could easily "injures them in almost all the prospects and hopes they might conceive" (Dworkin, 2000, p. 407). Therefore, the correct path to achieve a diversified and integrated community is primarily to lift the curse on blacks.

What can we make of the similarities and differences between Dworkin (1985) and Dworkin (2000)? It is obvious that Dworkin (1985) did not explicitly present any forward-looking argument. Dworkin's concern there seems to be centered on helping the blacks, which could come with a compensatory tone. However, we do not think that Dworkin has changed his view. He is simply developing his view into a more sophisticated version. The focus on helping the blacks does not have to be compensatory, or backward-looking. It is still consistent with a forward-looking argument because the forward-looking argument still has to take into consideration what happened in the past in order to decide what actions are appropriate and fair to build a better future of diversity and integration. And we should not overlook that the fundamental insight of asymmetry of discrimination remains the same, playing important roles in the arguments.

Dworkin is inclined to support Category 4. In Dworkin's $(1985,1986,2000)$ view, the equal protection under the law does not literally mean that the government cannot make special laws for disadvantaged groups. In contrast, equal protection is also applied to protecting minorities. The equal protection clause is violated when some group's loss results from its special vulnerability to prejudice, hostility, or stereotype. Each person receives only a guarantee of being treated with equal respect, but to achieve this goal sometimes requires special treatment. To be specific, this policy promises a better educational environment in terms of diversity and promotes a less racially stratified society for all citizens. Racism has harmed all 
members of society, and fostering opportunities for different races to study and work together is considered an effective remedy. Further, universities should not admit applicants for past achievements only. Instead, they have a responsibility to choose promising students who will contribute to the institution's educational, academic and social goals. If a race-based policy can offer a better education to everyone in a racially diverse setting, then this judgment is no more unfair to anyone than its judgment that it can do better with a geographically diverse class or with athletes as well as scholars.

Dworkin heavily cited "The Shape of the River" conducted by Bowen and Bok (1998) in attempting to substantiate his claim. It is important to note that in Glazer's view (1999), the arguments provided by the River Study for the affirmative action program involve practical consequences rather than principles. While citing the study's statistical analysis, it seems that Dworkin tried to shift the focus of the arguments from the practical level to the principle level. Nonetheless, it is important to point out that for Dworkin the legitimacy and fairness of a legal interpretation is established through "testing" its "fit" against the practical aspect of the law. Dworkin's method is based on a factual-historical analysis, rather than an ontological argument (Anderson, 1999). It is difficult, if not impossible, to distinguish the principle level from the practical level. Specifically, for Dworkin the concept of fairness is built on claims of improving the general interests of the community resulting from implementing the affirmative action program. To examine whether affirmative action in principle is fair or not, it is essential to evaluate the statistical results and interpretation of the River Study. In the following analysis, we will approach this issue on both the principle and empirical levels.

\section{The Diversity and The General Interest Arguments}

Dworkin (1985) pointed out that the US "will continue to be pervaded by racial division as long as the most lucrative, satisfying, and important careers remain mainly the prerogative of members of the white race" (p. 294). As a remedy, Dworkin (2000) argued that by increasing the number of blacks on campus, affirmative action enriches the educational opportunities of other students, including whites. A diversified learning environment will better prepare all students to function in a pluralistic society. Even though the policy may seem to be unfair to certain applicants in the short run, it increases the general interests of society in the long run. However, his argument developed back in 1985 and 2000 seems outdated because today the American pluralistic society is not composed only of blacks and whites. For several decades, America has attracted a large number of immigrants from all over the world. Today, it is more likely that a white college graduate would work with people from a wide diversity of countries and ethnic groups. According to the Bureau of Labor Statistics (2013), in $201216.1 \%$ of the US labor force is foreign-born. Moreover, in the age of globalization, American companies have been increasing the level of interaction with people in other nations. If racial and cultural diversity is useful in building a richer learning environment where cultural awareness is taught, then increasing the number of immigrants and international students should also be considered an important goal because it could further broaden a student's cultural horizons.

Dworkin (2000) insisted that officials could make decisions to "benefit some citizens and disadvantage others," and the decisions "are in the general interest of the community as a whole" (p. 411). By the same token, universities and colleges "must choose goals to benefit a much wider community than their own faculty and students" (p. 402). However, even if the involuntary sacrifice of a small number of white and Asian applicants could improve the overall welfare of a wider community, it is still unfair to deprive some individuals of their rights to serve the "general interest" of a community. By examining university admission data, Espenshade and Radford (2009) found that Asian-Americans needed an average SAT score of 1550 to be accepted at a top private university, while whites needed an average score of 1410 and African Americans needed an average score of 1100 . In the utilitarian view, it may be justified to make a small number of people unhappy in order to maximize the overall happiness of the majority. Nonetheless, even if one takes a utilitarian approach to justify this policy (an approach that Dworkin would not accept, as we explained in the previous section), the consequence may still not be what one expects. While the River Study made many counterfactual calculations of how blacks might be worse off if rejected by selective institutions, do we realize the potential consequence to society when qualified whites and Asians are rejected by top universities? Who could know how many Nobel Prize winners or innovators America has lost as a result of rejecting more qualified candidates? There is no evidence that the sacrifice of a small number of people will contribute to a better society.

In contrast, there is evidence that race-based admissions and hiring policies would harm the society as a whole. Take Malaysia as an example. Malaysia is a racially-diverse country, which is composed of Malays, Indians, Chinese people, and other minorities, including Orang Asli (Aborigines of Peninsular Malaysia), Eurasians, and the indigenous groups of Ibans, Kadazan, Dusuns, Bidayuhs, and Murut. Malays are the ruling majority while the Indian and Chinese people are 
significantly smaller minorities in terms of number. Indians and Chinese people outperform Malays in both academic and economic achievements. To empower the Malay group, the government implements its own version of "affirmative action," setting different admissions and hiring standards for different ethnic groups. As a result, many talented people lost the opportunity to actualize their potential. In 1965, a group of Chinese separated themselves from Malaysia to form an independent country-Singapore. Singapore adopted a racially-neutral policy in virtually all aspects of their society. Within a decade, Singapore became one of the "four tigers" in Asia. In terms of area and population, Singapore is a much smaller country than Malaysia. The size of Singapore is only 263 square miles and the population is about 4 million, whereas Malaysia covers 127,316 square miles of land and has a population of 23 million. Despite this disparity, Singapore's sophisticated manufacturing infrastructure and technological advancements have made her a regional giant. In 2016, the GDP of Singapore was almost US $\$ 297$ billion while the per capita GNP approached US $\$ 52,600$. In contrast, the 2016 GDP of Malaysia was almost US $\$ 275$ billion and the per capita GNP was only \$US11,028 (Trading Economics, 2017). Therefore, we do not need a counterfactual argument or a thought experiment; the comparison between Malaysia and Singapore illustrates that depriving a small number of people their rights and suppressing their talents makes a worse, not a better society. Candidly, Malaysia has been hurt by her own policy. Should a policy be considered fair if the so-called overall fairness in terms of total welfare of a wider community is not achieved?

The River Study made a counterfactual but unconvincing calculation of the damage to whites and Asians under the affirmative action program. Bowen and Bok (1998) pointed out that even if race-sensitive admission policies were abolished, the number of white and Asian applicants in top institutions would not increase significantly. Among thousands of white and Asian applicants who believed the policy would affect their admission, in reality only a few were denied due to the policy. However, no matter how minimal the impact of the policy is on whites and Asians, this argument does not successfully defend the "fairness" or explain the "unfairness" of the policy. In the 1980s, the US and Japan clashed over trade policies. The former embraced full access to the free market, while the latter endorsed protectionism. One argument used by the Japanese was: The lost market share that Americans complained about was insignificant. Even if all trade barriers were removed, it would not have reversed the trend of the trade imbalance. By the same token, no matter how minor the impact of trade barriers is on American companies, it does not change the fact that trade barriers are unfair. In short, using "insignificance" as an argument does not defend fairness.

Bowen and Bok (1998) asserted that without the race-sensitive admission policy some blacks could not have been admitted to selective universities such as Harvard. As a result, counterfactually speaking, those universities would not have been culturally diverse and those blacks would not have led successful lives. There are two problems with this argument. First, if those black applicants were rejected by selective universities, they could have been admitted to less selective universities. Don't less competitive universities also need a diversified environment? One of the goals of equality is to help those who are disadvantaged. When less prestigious colleges are in a disadvantageous position compared to top universities, doesn't it make sense for these schools to increase their diversity to enhance the learning environment and educational opportunities? In 1996, the State of California passed Proposition 209, which prohibited public institutions from using racebased admission policies. Although the black and Hispanic enrollment was reduced at the most prestigious University of California campuses (-42\% at UC Berkley; $-37 \%$ at UCLA), other less competitive UC campuses increased their black and Hispanic enrollment (+22\% at UC Irvine, $+18 \%$ at UC Santa Cruz; $+65 \%$ at UC Riverside) (Sander \& Taylor, 2012). Basically, overall diversity of more UC campuses improved as a result of Proposition 209.

Second, Dworkin defined true equality in terms of the resources that each person commands, not in the success he or she achieves. Why is it important for minorities to attend top universities if career success, earning power, social status, etc. are not the objectives of equality? Do less prestigious colleges also provide sufficient learning resources for minorities to lead successful lives in a non-materialistic sense? Dworkin (2000) emphasized that without affirmative action, "scarcely any Black students will be admitted to the best law and medical schools. That would be a huge defeat for racial harmony and justice" (p. 410). Why is it necessary to achieve racial harmony and justice by providing resources in the best law and medical schools? The authors of this article didn't graduate from Yale or Harvard, but we never complain.

\section{The Forward-Looking Argument}

Dworkin emphasized that his approach concerning affirmative action is forward-looking; the admission policy should not solely focus on the past achievements of candidates. In Dworkin's view, we have to take the potential and the future outlook of the candidates into consideration. This argument seems confusing. We forecast the future based on past data. It is common to predict an individual's future based on his/her past performance. As a matter of fact, although selective 
universities take many factors into consideration during the admissions process, the single-most important one is the likelihood of success in the school's academic program. It is generally agreed that SAT scores and high school grades are good predictors of college performance. But SAT scores and high school grades over-predict the performance of blacks in college (Sandalow \& Bowen, 2003). In other words, past achievements in terms of test scores suggests that blacks with lower scores are not promising students. It is not clear what other specific criteria Dworkin employed to justify his forwardlooking admission approach.

Perhaps contribution to the community is one of the forward-looking criteria. Nonetheless, it is unclear how the admissions board could judge whether an applicant would be a community leader after graduation. Although the River Study mentioned that blacks who graduated from selective universities tend to take leadership roles or participate in community activities, it is not clear whether the active community involvement is concentrated in organizations whose activities primarily affect other relatively privileged blacks or if they also participated in community activities which can help disadvantaged blacks (Sandalow \& Bowen, 2003). More importantly, even though black professionals provide leadership in the community, and even in the political arena, it does not guarantee that the overall well-being of disadvantaged blacks could be promoted. Sowell (1999) pointed out that Asian-Americans have no leader of their own like Jesse Jackson, who speaks for blacks, but they seem to do better than those who have political leaders.

\section{Evaluation of Empirical Merits of the River Study}

Next, we will examine the validity of Dworkin's arguments and the River Study on the empirical level. According to Epstein (1999), the River Study omitted some highly selective universities such as Harvard and the University of Chicago, as well as most major state universities, including those in the California and Texas educational systems. Similarly, Trow (1999) also questioned the generalizability of the River Study by arguing that Bowen and Bok highlighted only a small number of successful black graduates, but failed to prove that these benefits would not be undone by larger harms for higher education and society as a whole. Sowell (1999) also criticized that the sample used in the River Study is not representative. For example, at Berkeley, the graduation rate of blacks is about 30 percent, but Berkeley is not included in the River Study. Further, although Bowen and Bok asserted that one of the important measures of success in college is the graduation rate and the high graduation rate among blacks means that racial preference does not lead to the admission of unqualified students, we should be cautious because they did not partition the dataset into race-neutrally admitted blacks and specially admitted ones. Instead, their discussion of the graduation rate included all black students.

In addition, although the River Study seems to be supported by a sea of statistical figures, the meaning of these numbers is subject to the analysis and interpretation of the researchers. In other words, one may call a glass filled with 50 percent water "half-full" or "half-empty." It is important to note that a large portion of data are soft opinions regarding perceived experience and satisfaction, but Bowen and Bok treated them as hard data. While enhancing diversity plays a central role of their support for preferential admission, Bowen and Bok didn't cite survey responses to support this assertion. Therefore, Orlans (1999) questioned its validity noting, "The book seems less an objective report of an empirical inquiry than an advocate's well-researched brief for preferential admission" (p. 187).

The River Study pointed out that black students earn grades that typically place them at the twenty-third percentile of their class. Neither Dworkin nor Bowen/Bok addressed the problem of lower performance. Instead they gave optimistic generalizations and praised their achievements as impressive. Based on different empirical data, Sander (2005) found the otherwise. Sander argued that although during the past 30 years American law schools has been implementing race-based affirmative action with the noble intention to help African-American law students, this policy actually is detrimental to the group. Sander found that on the average black law students admitted through preferences have low grades. It is not because of any racial characteristic, but because the preferences themselves put them at an enormous academic disadvantage. The median black student starting law school in 1991 received first-year grades equivalent to a white student at the 7th or 8th percentile. Further, this poorer performance substantially hinders black students from graduation and certification. Only 45 percent of black law students in the 1991 group completed law school and passed the bar on their first attempt. Sander counterfactually argued that without preferential admissions, this rate would have risen to 74 percent. A few years later in 2012, Sander and Taylor followed up this study with additional data. They found that at the UCLA Law School only 50 percent of black students and 70 percent of Hispanic students were able to pass the bar exam, compared with 90 percent of white students. However, the pass rate of black students who attended other law schools is between 75 percent and 80 percent while the pass rate of Hispanic students ranges from 80 to 85 percent. Sander and Taylor concluded that the race-based admission policy at the UCLA Law School unintentionally created a "mismatch" problem: black and 
Hispanic students were placed into a competitive environment that they were under-prepared for, and consequently the affirmative action program harmed the students that it is intended to help.

Sander and Taylor (2012) went beyond law school data by comparing overall UC data before and after Proposition 209. Proposition 209 encountered very strong resistance because people were afraid going forward the enrollment of blacks and Hispanics would drop substantially. Truly, after Proposition 209 there was a 50-percent reduction in black freshman enrollment and a 25-percent drop for Hispanics. Nevertheless, the total number of black and Hispanic students earning bachelor's degrees was the same for the five classes after Proposition 209 as for the five classes before the proposition. Before Proposition 209, the black and Hispanic graduation rate was 63 percent but in the post-Proposition 209 era, it increased slightly to 69 percent. Sander and Taylor argued that when more qualified black and Hispanic students were admitted into the UC system, it alleviated the mismatch problem, resulting in a higher graduation rate.

However, Kidder and Onwuachi-Willig (2014) argued against the preceding assertion. They bluntly pointed out that Sander and Taylor's calculation was flawed because they reported the average graduation rate of adjacent years. When each year was examined individually, there was no substantive upward trajectory. However, even though the gain of the minority graduation rate was, as Kidder and Onwuachi-Willig (2014) said, "... less impressive, if not disappointing..." (p. 912), it still cannot negate Sander and Taylor's notion. Before the implementation of Proposition 209, many critics predicted that eventually blacks and Hispanics would disappear from the UCLA campus (Sander \& Taylor, 2012). Bowen and Bok (1998) were among those critics. They worried that if racial preference was banned in college admission, prestigious schools would become all-white campuses; racial tensions would get worse when top jobs in government and business were dominated by whites. However, a flat trend of black and Hispanic graduation rates before and after Proposition 209 indicates that the opportunities of black and Hispanics were not affected by color-blind admission policies.

\section{Conclusion}

Although Dworkin admirably attempted to give an argument for fairness that is backed by an empirical study, the authors found that Dworkin's theory does not have good empirical support and the normative argument is undermined by its shaky implicit empirical presumption. This casts more doubt on the fairness of Category 4 affirmative action. Specifically, the sample used in River Study is unrepresentative, and the results are open to interpretation. If legitimacy and fairness of a policy is a matter of the fit between the theory and the practical consequence, would changing the racial composition within the country, including the increasing number of immigrants and changing a country's role in the international community such as globalization, affect the current meaning of diversity? Moreover, although diversity seems to be a reasonable goal, Dworkin's persistence in requiring blacks to be admitted to elite universities as essential for justice is probably outdated now in this more diversified US society, because it is no longer easy to identify which racial communities are seen by others as public insult. Perhaps there exist now different kinds of discrimination from one group to another. Finally, from a utilitarian point of view, the question of fairness remains unanswered because the lesson of Singapore and Malaysia shows that the general interest of society is not warranted by a policy of giving special treatments to certain groups at the expense of other groups.

\section{References}

[1] Anderson, E. S. (2010). The Imperative of Integration. Princeton, NJ: Princeton University Press.

[2] Anderson, J. C. (1999). Why lawyers derail justice: Probing the roots of legal injustices. University Park, PA: Pennsylvania State University Press.

[3] Altman, A. (2001). Policy principle, and incrementalism: Dworkin's jurisprudence of race. Journal of Ethics, 5 , 241-262.

[4] Boddie, E. (2016, June). The future of affirmative action. Harvard Law Review, 139(1), 38-50.

[5] Bowen, W. G., \& Bok, D. (1998). The shape of the river: Long-term consequences of considering race in college and university admissions. Princeton, NJ: Princeton University Press.

[6] Bureau of Labor Statistics. (2013). Foreign-born workers in the U.S. labor force. Retrieved from https://www.bls.gov/spotlight/2013/foreign-born/

[7] Dworkin, R. (1985). A matter of principle. Cambridge, MA: Harvard University Press.

[8] Dworkin, R. (1986). Law's Empire. Cambridge, MA: Harvard University Press.

[9] Dworkin, R. (2000). Sovereign virtue: The theory and practice of equality. Cambridge, MA: Harvard University Press. 
[10] Epstein, R. (1999). Unexplored tributaries. Reason, 30, 61-67.

[11] Espenshade, T. J., \& Radford, W. (2009). No longer separate, not yet equal: Race and class in elite college admission and campus life. Princeton, NJ: Princeton University Press.

[12] Glazer, N. (1999). The case for racial preferences. Public Interest, 135, 45-63.

[13] Justia. (2016). Regents of Univ. of California v. Bakke 438 U.S. 265 (1978). Retrieved from https://supreme.justia.com/cases/federal/us/438/265/

[14] Kennedy, J. F. (1961, March 6). Executive Order 10925-Establishing the President's Committee on Equal Employment Opportunity. The American Presidency Project. Retrieved from http://www.presidency.ucsb.edu/ws/?pid=58863.

[15] Kidder, W. C., \& Onwuachi-Willig, A. (2014). Still hazy after all these years: The data and theory behind "mismatch". Texas Law Review, 92, 895-941.

[16] Legal Information Institute. (2003). Grutter V. Bollinger (02-241) 539 U.S. 306 (2003) 288 F.3d 732, affirmed. Retrieved from https://www.law.cornell.edu/supct/html/02-241.ZO.html

[17] Liptak, A. (2016, June 23). Supreme Court upholds Affirmative Action Program at University of Texas. New York Times. Retrieved from https://www.nytimes.com/2016/06/24/us/politics/supreme-court-affirmative-actionuniversity-of-texas.html?mcubz=0

[18] Nixon, R. (1971, Oct. 13). Executive Order 11625: Prescribing additional arrangements for developing and coordinating a national program for minority business enterprise. Retrieved from https://www.archives.gov/federal-register/codification/executive-order/11625.html

[19] Orlans, H. (1999). Reviewed work: The shape of the river: Long-term consequences of considering race in college and university admissions. Minerva, 37(2), 185-190.

[20] Sabbagh, D. (2011). The rise of indirect affirmative action: Converging strategies for promoting "diversity" in selective institutions of higher education in the United States and France. World Politics, 63, 470-508.

[21] Sandalow, T., \& Bowen, W. G. (1999). Minority preferences reconsidered. Michigan Law Review, 97 , 1874-1928.

[22] Sander, R. (2005). A systemic analysis of Affirmative Action in American Law Schools. Retrieved from http://www1.law.ucla.edu/ sander/Data\%20and\%20Procedures/StanfordArt.html

[23] Sander, R., \& Taylor, S. (2012). Mismatch: How affirmative action hurts students it's intended to help, and why universities won't admit it. New York, NY: Basic Books.

[24] Sowell, T. (1999). Misshapen statistics on racial quotas. American Spectator, 32, 24-27.

[25] Taylor, R. (2009). Rawlsian Affirmative Action. Ethics, 119, 476-506.

[26] Trading Economics. (2017). GDP by country. Retrieved from https://tradingeconomics.com/country-list/gdp

[27] Trow, M. (1999, Spring). "The shape of the river": California after racial preferences. Public Interest, 135, 64-85.

[28] University of Chicago (2017). Tutoring and enrichment. Retrieved from https://civicengagement.uchicago.edu/education/tutoring-enrichment/ 